\section{CG FARRAPO: a sudangrass cultivar with high biomass and grain yields}

\section{Emilio Ghisleni Arenhardt ${ }^{1^{*}}$, José Antonio Gonzalez da Silva ${ }^{2}$, Ewerton Gewehr ${ }^{3}$, Lorenzo Ghisleni Arenhardt' ${ }^{2}$, Celso Luis Are- nhardt $^{4}$ and Gilmar Nonnenmacher ${ }^{4}$}

\begin{abstract}
The new sudangrass cultivar [Sorghum sudanense (Piper) Stapf.] was developed by the method of selection of individual plants with progeny testing. The most important traits are high biomass yield with high grain yield.
\end{abstract}

Key words: Sorghum sudanense (Piper) Stapf., plant breeding, forage traits, grain yield.

\section{INTRODUCTION}

The diversification of annual summer crops for forage production is highly desirable, since production costs of conventional crops, such as maize (Zea mays L.) and sorghum [Sorghum bicolor (L.) Moench] are high (Neumann et al. 2010). In animal production, the reduction of costs allied to yield and to forage quality are basic requirements for the success of livestock activities. Thus, the employment of physiologically most efficient plants in the use of light, nutrients and water is highly desirable (Penna et al. 2010). Sudangrass [Sorghum sudanense (Piper) Stapf.] is reported for having great ability in tolerance to drought, to high soil acidity and lower fertility, to heat, to foliar diseases and it has great competitive ability over weeds. Therefore, it is highly adapted to hot and dry climates, presents high biomass production, and its recovery after cutting of grazing is superior to most annual grasses (Bibi et al. 2010).

In silage production, maize is considered the standard species. However, its production and quality are uncertain due to the strong sensitivity to water stress (Martin et al. 2012). On the other hand, sorghum has shown production similar to maize, especially in regions where low rainfall is observed, which may facilitate the replacement of maize by sorghum in silage processing ( $O^{\prime}$ Kennedy et al. 2006). Cultivation of sorghum or sudangrass evidences lower costs with seeds; lower production cost; high biomass yield, and the nutrition value of the produced forage is equivalent to 85 to $90 \%$ of maize silage, without the need of any additive to improve fermentation (Von Pinho et al. 2007). According to Neumann et al. (2004), the use of dual-purpose sorghum to replace maize in confined animal feeding does not alter the consumption of the dry matter, the weight gain and the feed conversion. Forage sorghum and/or sudangrass are of great importance for animal production, evidencing the high productive potential. Their quality is recognized as a source of energy for animal feeding, either as silage, cutting or direct grazing (Montagner et al. 2005). It should be highlighted that the proportion of grains is a determinant factor for the quality
Crop Breeding and Applied Biotechnology 16: 158-162, 2016 Brazilian Society of Plant Breeding. Printed in Brazil http://dx.doi.org/10.1590/1984$70332016 v 16 n 2 c 24$
*Corresponding author: E-mail: emilio.arenhardt@yahoo.com.br

Received: 21 June 2014 Accepted: 15 January 2016

${ }^{1}$ Universidade Federal do Rio Grande do Sul (UFRGS), Faculdade de Agronomia, Departamento de Plantas de Lavoura, Av. Bento Gonçalves, 7712, 91.501-970, Porto Alegre, RS, Brazil

${ }^{2}$ Universidade Regional do Noroeste do Estado do Rio Grande do Sul, Departamento de Estudos Agrários, Rua do Comércio, 3000, Bairro Universitário, 98.700-000, ljuí, RS, Brazil

${ }^{3}$ Universidade Federal de Pelotas (UFPel), Faculdade de Agronomia 'Eliseu Maciel'(FAEM), Ciência e Tecnologia de Sementes, Departamento de Fitotecnia, Campus Universitário Capão do Leão, 96.010-610, Pelotas, RS, Brazil

${ }^{4}$ Empresa Celso L. Arenhardt \& Cia Ltda (Cegil Agro Sementes), Rodovia RS 522, km 18, vila Ijuizinho, 98.740-000, Augusto Pestana, RS, Brazil 
of the silage, and it is the largest available energetic fraction of this plant (Oliveira et al. 2005). Thus, in the production of a good silage, besides the high biomass yield, the high participation of grains in the ensiled mass is decisive for the quality of the elaborate product (Zopollatto et al. 2009). Also, it has been verified that the inclusion of dual-purpose sorghum silage with high participation of grains in the ensiled mass in animal's diet has provided greater net income per confined animal (Neumann et al. 2004).

\section{PEDIGREE AND BREEDING METHODS}

The cultivar CG FARRAPO was obtained by the method of selection of individual plants within the "common" original population with subsequent progeny test (tests of value of cultivation and use - VCU). In the year of 2009, three populations of "common" sudangrass, originated from different edaphoclimatic regions, were sown in the field, evidencing great genetic variability within and between populations. Two populations were collected in the fields of Cegil Agro Seeds company, in São Borja - Rio Grande do Sul, and in Campos de Júlio - Mato Grosso, and another one was collected by farmers in the municipality of Melo (province of Cerro Largo, Uruguay). Seeds of each population were sown $0.45 \mathrm{~m}$ between plants and between rows, on a density of three to four seeds per pit-hole. The established order sought to force competition between plants in the pit-hole, and the one which expressed greater competitive ability in the vegetative stage would remain. There was selection pressure of approximately $3 \%$ in 1272 of the plants obtained from three populations, based on forage traits (produced biomass) and grain yield, such as length, infertility, weight of panicle, number and grain weight per panicle. In the field, the main trait of analysis was tillering, and it was selected plants, which had at least 10 fertile tillers (viable panicles). These plants were cut close to the soil surface at the physiological maturity of seeds, separating the panicles for kiln drying $\left(40^{\circ} \mathrm{C}\right)$ until seed moisture reached close to $13 \%$, and the rest of the genotype of each plant was weighed in order to assume the potential for biomass production. Before cutting, the main panicle of each plant was identified, harvested and packed in paper bags for drying, and were directly taken to the laboratory for analysis of traits related to the inflorescence components, such as panicle length,

Table 1. Agronomic Performance of forage cultivars of the trials of value for cultivation and use, carried out in 2011 , in three different soil and climatic regions

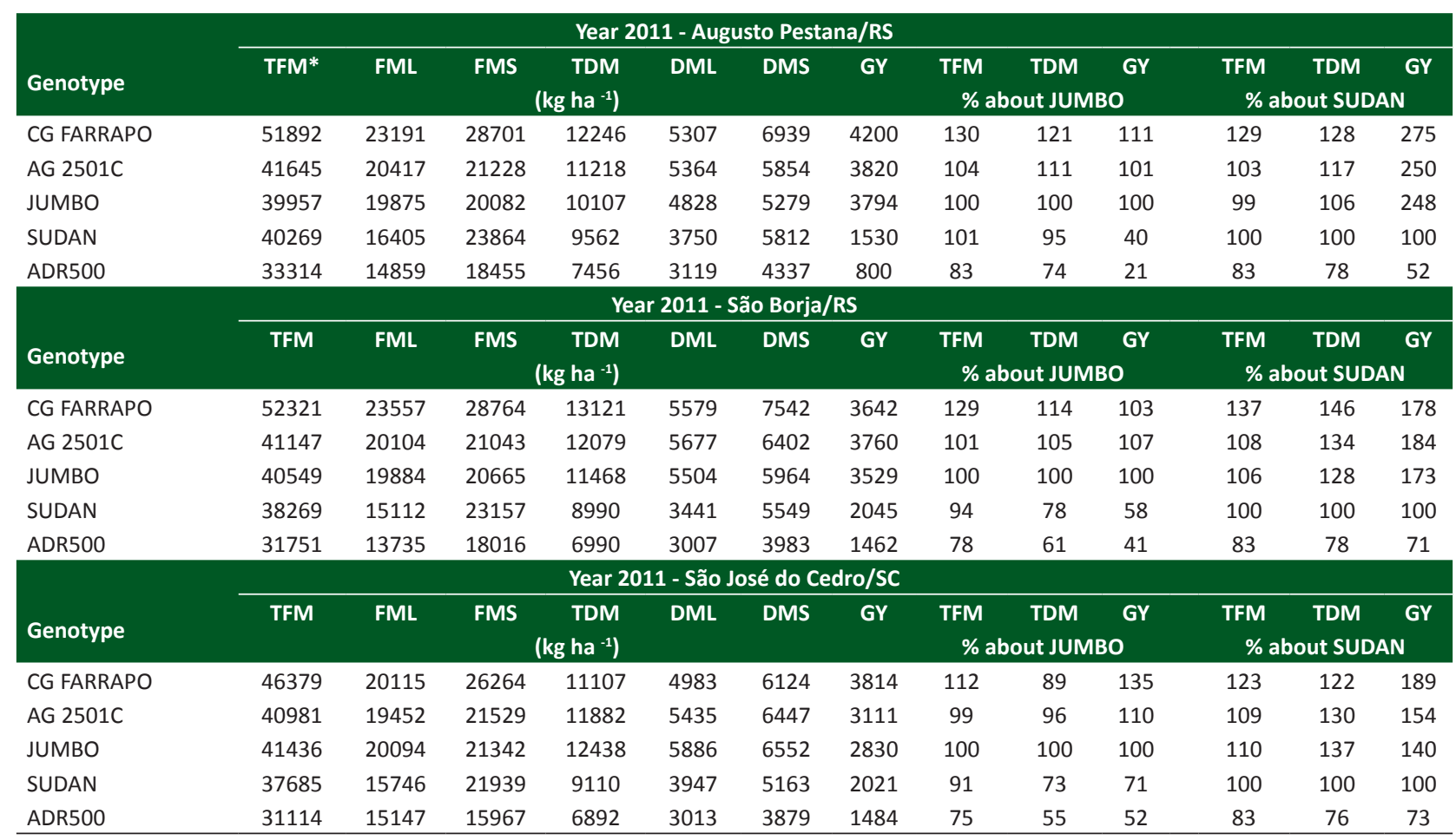

* TFM= Total Fresh Matter; FML= Fresh Matter of Leaves; FMS= Fresh Matter of Stalks; TDM= Total Dry Matter; DML= Dry Matter of Leaves; DMS= Dry Matter of Stalks; $\mathrm{GY}=$ Grain Yield. 
panicle weight, number of panicle grains, weight of panicle grains, fertility, and panicle harvest index. Thus, after the analysis of the selected genotypes, plants with higher performance for the simultaneous production of forage and seeds were sown in the field, in 2010, in individual plots. In that year, selection occurred between plots, and the selected plots needed to present great uniformity and superior performance. The selected plots were submitted to VCU tests in the following years. The cultivar was called CG 393AR09 in the field.

\section{PERFORMANCE}

Due to its great potential in biomass yield and grain, in the years of 2011 and 2012, the line CG 393AR09 was tested in VCU tests carried out at three different locations: Augusto Pestana (lat 28 28' 51' S, long 53 58' 07' W, alt 385 m asl) and São Borja (lat 28 54' 40" S, long 55 29' 06" W, alt 137 m asl) in the state of Rio Grande do Sul, and in São José do Cedro (lat 26 27' 46" S, long 53 32' 53" W, alt $627 \mathrm{~m}$ asl) in the state of Santa Catarina. Tests were carried out in a randomized block design with four replications. Each experimental unit, which included a genotype to be tested, consisted of five $5 \mathrm{~m}$ rows spaced $0.20 \mathrm{~m}$ apart, in order to compose a $5 \mathrm{~m}^{2}$ plot. Seeding rate was $25 \mathrm{~kg} \mathrm{ha}^{-1}$ of seeds for cultivars of sudangrass and pearl millet, and $12 \mathrm{~kg} \mathrm{ha}^{-1}$ of seeds for sorghum cultivars. The evaluated traits were the total production of fresh matter (TFM) by $1 \mathrm{~m}^{2}$ cutting of each plot, every time plants reached $60-65 \mathrm{~cm}$ height, leaving a $10 \mathrm{~cm}$ residue above the soil. Samples of each genotype were weighed to obtain the TFM, and then, 100 grams were used for botanical separation. Therefore, it was analyzed the fresh matter of leaves (FML) and the fresh matter of stalks (FMS), and after that, they were converted to $\mathrm{kg} \mathrm{ha}^{-1}$. Subsequently, samples were placed to dry in an oven with forced air circulation at $65{ }^{\circ} \mathrm{C}$ until constant weight, for another analysis, and to obtain estimates of total dry matter (TDM), dry matter of leaves (DML), and dry matter of stalks (DMS).

For analysis of grain yield, another experiment was carried out in order to obtain greater reliability of selection applied on the components of grain yield of the cultivar. Thus, the experiment was carried out in randomized block design with three replications. Each experimental unit, which included a genotype to be tested, consisted of five $5 \mathrm{~m}$ rows spaced

Table 2. Agronomic Performance of forage cultivars of the trials of value for cultivation and use, carried in 2012 , in three different soil and climatic regions

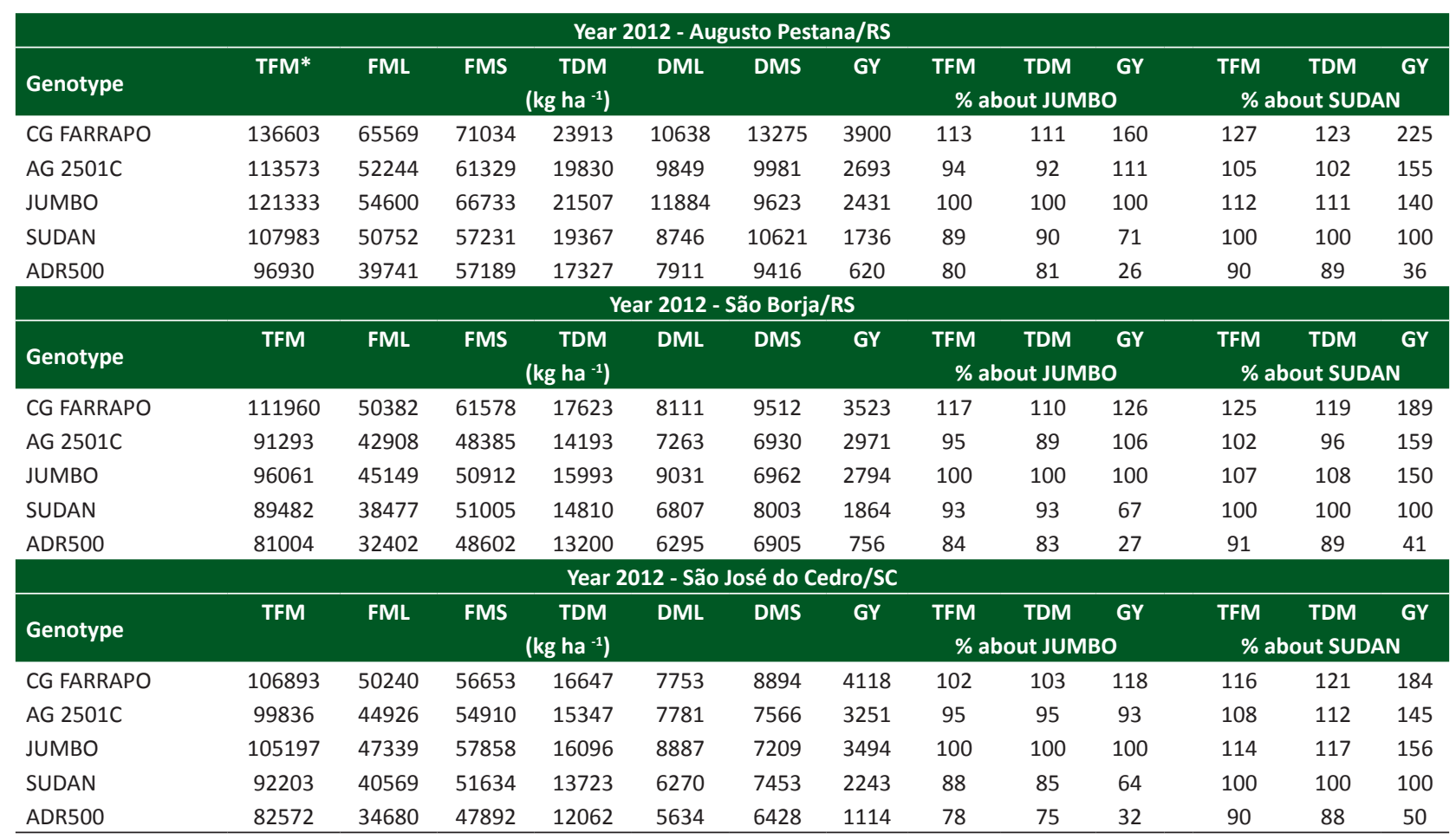

* TFM= Total Fresh Matter; FML= Fresh Matter of Leaves; FMS= Fresh Matter of Stalks; TDM= Total Dry Matter; DML= Dry Matter of Leaves; DMS= Dry Matter of Stalks; GY= Grain Yield. 
$0.20 \mathrm{~m}$ apart, in order to compose a $5 \mathrm{~m}^{2}$ plot. Seeding rate was $25 \mathrm{~kg} \mathrm{ha}^{-1}$ of seeds for cultivars of sudangrass and pearl millet, and $12 \mathrm{~kg} \mathrm{ha}^{-1}$ of seeds for sorghum cultivars. To estimate grain yield, it was carried out harvesting of the three central rows of each plot, comprising an area of $3 \mathrm{~m}^{2}$, as soon as seeds reached the stage of physiological maturity. Panicles were weighed and threshed with values estimated in $\mathrm{kg} \mathrm{ha}^{-1}$. For not having available seeds of this cultivar (IPA Sudan 4202) registered at the Ministry of Agriculture, Livestock and Supply-MAPA when the study was carried out, it was used as control, in both experiments, one pearl millet (ADR 500 - "SuperMassa"), two hybrid forage sorghum cultivars (AG2501C and JUMBO), and the sudangrass "common" population. In these same years, in Augusto Pestana, the experiment was carried out with the purpose of doing the DHS (Differentiation, Homogeneity and Stability) tests, comparing with the same control cultivars.

In table 1, which shows the comparison between the cultivars in relation to forage and grain yield in 2011, the cultivar CG FARRAPO presented greater prominence, surpassing the traits total fresh matter, fresh matter of leaves, and stalks, when comparing to all the controls in the three evaluation sites. In the evaluation of the total dry matter and dry matter of stalks, the superiority of the cultivar CG FARRAPO was also observed in the environments Augusto Pestana and São Borja. Moreover, in São José do Cedro, thsorghum he ybrid JUMBO was the most productive. For dry matter of leaves, the hybrid AG2501C was superior in the environments of Rio Grande do Sul; however, in Santa Catarina, the cultivar JUMBO obtained the highest production of dry matter of leaves per hectare. It should be highlighted, for the

Table 3. Mean agronomic performance of forage cultivars of the trials of value for cultivation and use, carried out in the years of 2011 and 2012, in three different soil and climatic regions

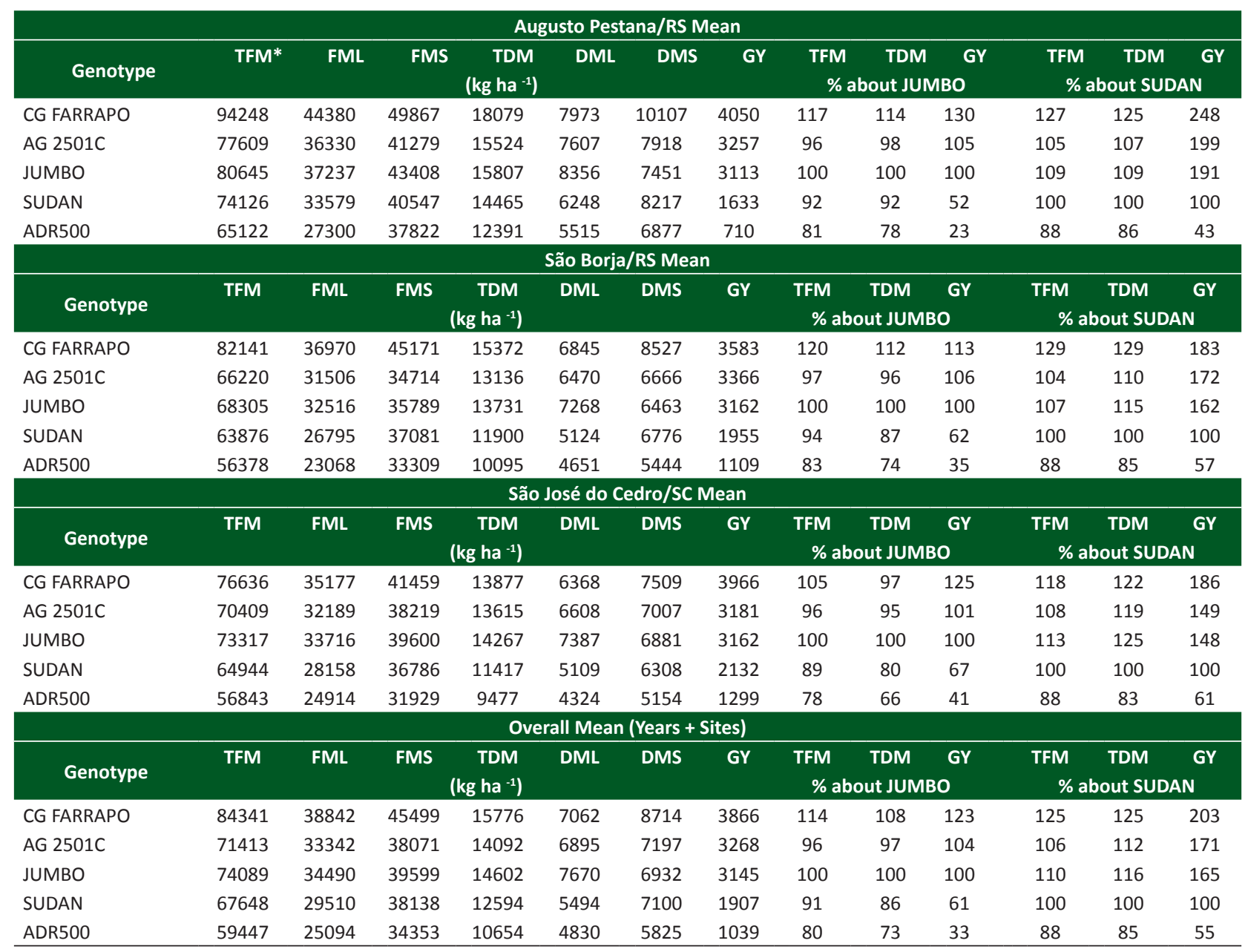

* TFM= Total Fresh Matter; FML= Fresh Matter of Leaves; FMS= Fresh Matter of Stalks; TDM= Total Dry Matter; DML= Dry Matter of Leaves; DMS= Dry Matter of Stalks; $\mathrm{GY}=$ Grain Yield. 
expression of grain yield, that only in the municipality of São Borja, RS, the cultivar CG FARRAPO did not achieve the highest performance. In the year of 2011, the pearl millet cultivar ADR 500 was inferior to the other genotypes for all traits. In the second year of evaluation of the VCU tests, CG FARRAPO stood out again for the highest productions both in the main forage traits and in grain yield, surpassing the control in all the evaluation sites (Table 2). In the year of 2012, due to climate favoring, all genotypes presented higher yields than the previous year, when the cultivar CG FARRAPO proved its great performance, and surpassed the forage hybrids mostly used by farmers in southern Brazil.

Table 3 presents the mean yield values of forage traits and grain yield in the two years at each site and the overall mean of both years in all of the sites. Thus, it is noted that the environment Augusto Pestana was the most favorable, while the environment São José do Cedro was the most restrictive. In this sense, the cultivar CG FARRAPO showed superiority for grain yield and for the main forage traits, when compared to the best controls, except for the total dry matter production in São José do Cedro, where the hybrid JUMBO achieved the best performance. Moreover, the high genetic gain obtained in the selection process of the new cultivar of sudangrass, with yield of fresh and total dry matter in $25 \%$ more than "common cultivar", increasing from 67648 and $12594 \mathrm{~kg} \mathrm{ha}^{-1}$ to 84341 and $15776 \mathrm{~kg} \mathrm{ha}^{-1}$, respectively. Moreover, it doubled grain yield, from $1907 \mathrm{~kg} \mathrm{ha}^{-1}$ to $3866 \mathrm{~kg} \mathrm{ha}^{-1}$ (Table 3). Cultivar CG FARRAPO surpassed the best control, cultivar JUMBO, in 14 and $8 \%$ in total fresh matter and total dry matter, respectively, besides producing on average $23 \%$ more grain per hectare.

\section{SEED MAINTENANCE AND DISTRIBUTION}

CG FARRAPO is registered in the Ministry of Agriculture, Livestock and Food Supply, under the register number 32395 (MAPA 2014). Cegil Agro Seeds (Celso L. Arenhardt \& Cia Ltda.) is responsible for maintaining the cultivar genetics and basic seeds. Seeds are sold to producers accredited by the company.

\section{REFERENCES}

Bibi A, Sadaqat A, Akram HM, Khan TM and Usman BF (2010) Physiological and agronomic responses of sudangrass to water stress. Journal of Agricultural Research 48: 369- 379.

MAPA- Ministério da Agricultura, Pecuária e Abastecimento (2014) Registro Nacional de Cultivares - Capim Sudão (Sorghum sudanense (Piper) Stapf.). Available at <http://extranet.agricultura.gov.br/php/ snpc/cultivarweb/detalhe_cultivar.php?codsr=32356> Accessed on April 16, 2014.

Martin JD, Carlesso R, Aires NP, Gatto JC, Dubou V, Fries HM and Scheibler RB (2012) Irrigação deficitária para aumentar a produtividade da água na produção de silagem de milho. Brazilian Journal of Irrigation and Drainage S1: 192-205.

Montagner DB, Rocha MG, Nörnberg JL, Chielle ZG, Mondadori RG, Estivalet RC and Calegari C (2005) Características agronômicas e bromatológicas de cultivares avaliados no ensaio Sul-Rio-Grandense de sorgo forrageiro. Revista Brasileira de Agrociência 11: 447-452

Neumann M, Restle J and Brondani IL (2004) Avaliação de silagens de sorgo (Sorghum bicolor (L.) Moench) ou milho (Zea mays L.) na produção do novilho superprecoce. Revista Brasileira de Milho e Sorgo 3: 438-452.

Neumann M, Restle J, Nörnberg JL, Oliboni R, Pellegrini LG, Faria MV and Oliveira MR (2010) Efeito associativo do espaçamento entre linhas de plantio, densidade de plantas e idade sobre o desempenho vegetativo e qualitativo do sorgo forrageiro. Revista Brasileira de Milho e Sorgo 7: 165-181.

O'Kennedy MM, Grootboom A and Shewry PR (2006) Harnessing sorghum and millet biotechnology for food and health. Journal of Cereal Science 44: 224-235.

Oliveira RP, França AFS, Filho OR, Oliveira ER, Rosa B, Soares TV and Mello SQS (2005) Características agronômica de cultivares de sorgo (Sorghum bicolor (L.) Moench.) sob três doses de nitrogênio. Pesquisa Agropecuária Tropical 35: 45-53.

Penna AG, Borges ALCC, Gonçalves LC, Rodrigues JAS, Gomes SP, Penna CFAM, Borges I, Rodrigues NM and Silva RR (2010) Produção de seis híbridos de sorgo com capim-sudão avaliados em três cortes e em duas épocas de semeadura. Revista Brasileira de Milho e Sorgo 9: 93-105.

Von Pinho RG, Vasconcelos RC, Borges ID and Resende AV (2007) Produtividade e qualidade da silagem de milho e sorgo em função da época de semeadura. Bragantia 66: 235-245.

Zopollatto M, Nussio LG, Mari LJ, Sschmidt P, Duarte AP and Mourão GB (2009) Alterações na composição morfológica em função do estádio de maturação em cultivares de milho para produção de silagem. Revista Brasileira de Zootecnia 38: 452-461. 